\title{
Capable Design or Designing Capabilities? An Exploration of Service Design as An Emerging Organizational Capability in Telenor
}

\author{
leva Martinkenaite ${ }^{1}$, Karl Joachim Breunig ${ }^{2}$ \\ and Annita Fjuk
}

\begin{abstract}
This empirical paper examines a process, starting with the managerial decision to make service design an organizational capability, and follows it as it unfolds over time within one organization. Service design has become an established business practice of how firms create new products and services to promote differentiation in an increasingly uncertain business landscape. Implicit in the literature on service design are assumptions about strategic implications of adopting the prescribed innovation methods and tools. However, little is known about how service design evolves into an organizational capability enabling firms to transform their existing businesses and sustain competitiveness. Through a longitudinal, exploratory case study of service design practices in one of the world's largest telecommunications companies, we explicate mechanisms through which service design evolves into an organizational capability by exploring the research question: what are the mechanisms through which service design develops into an organizational capability? Our study reveals the effect of an initial introduction of service design tools, identification of boundaryspanning actors and co-alignment of dedicated resources between internal functions, as well as through co-creation with customers. Over time, these activities lead to the adoption of service design practices, and subsequently these practices spark incremental learning throughout the organization, alter managerial decisions and influence multiple paths for the development of new capabilities. Reporting on this process, we are able to describe how service design practices were disseminated and institutionalized within the organization we observed. This study thus contributes by informing how service design can evolve into an organizational capability, as well

1 leva Martinkenaite, Vice-President, Telenor Research - Telenor ASA, Snarøyveien 30, N-1331 Fornebu, Norway, e-mail: ieva.martinkenaite@telenor.com.

2 Karl Joachim Breunig, Professor, Oslo Business School - Oslo and Akershus University College, PB 4 St. Olavs PI., N-0130 Oslo, Norway, e-mail: karl.joachim.breunig@hioa.no.

3 Annita Fjuk, Fellow. Telenor Research - Telenor ASA, Snarøyveien 30, N-1331 Fornebu, Norway, e-mail: annita.fjuk@ telenor.no.
\end{abstract}


as by bridging the emerging literature on service design and design thinking with established strategy theory. Further research will have to be conducted to confirm if the same mechanisms are observable across contexts and in other firms, and several future research directions are identified. In addition, the study also has implications for practice as it demonstrates how service design methodology can be implemented and has strategic implications for organizations.

Keywords: capability development; design thinking; organizational capabilities; service design practices; strategy-innovation link.

\section{INTRODUCTION}

Service design is a rapidly evolving business practice - a buzzword 'du jour' of service innovation, which has created significant business and research attention over the past years (Brown, 2009; Kimbell, 2014; Lockwood, 2010; Reason, Løvlie \& Flu, 2015; Stickdorn \& Schneider, 2012). Empathy with users and co-creation, rapid prototyping, iterative learning and tolerance for failure are essential elements of how services are designed, delivered and experienced according to a service design framework. For some industry giants such as IBM, Samsung and GE, among others, service design has become more than a means for innovation. These firms have embraced service design as a core competence (Prahalad \& Hamel, 1990) to discover new markets, create new organizational forms and ways of work, and manage change in increasingly volatile and complex service ecosystems (Yoo \& Kim, 2015). Essentially, design thinking has become a primary set of management principles enabling large industrial organizations to servitize their business and transform into the modern entities of the digital age (Kolko, 2015).

Despite the strategic implications of service design (e.g., Brown 2009), theorizing it as an organizational capability has largely been missing in the management and strategy literature (Gruber, de Leon, George \& Thompson, 2015). We still know little about how service design processes are routinized in the organization, and what implications they have on organizational structure, culture, work practices or performance (ibid). Consequently, extant literature has not sufficiently elaborated on the service design - strategy link. Bridging these two research areas may provide an end-to-end process understanding of capability development in modern organizations. Given that actors (customers, employees and third parties) are at the epicenter of design thinking (Kimbell, 2014), the lens provided by service design literature may also reveal how actors contribute to capability life-cycles and multiple development paths for organizational capabilities (Bingham, Heimeriks, Schijven \& Gates, 2015; Helfat \& Peteraf, 2015). 
In this paper, we theorize service design as a recipe for organizational capabilities in-the-making. We seek to explain when (under what conditions) and how service design practices are diffused throughout an organization, become institutionalized (Crossan, Lane \& White, 1999), and affect decision making processes and performance. More specifically, we ask: what are the mechanisms through which service design develops into an organizational capability?

The context in which we seek answers is the Telenor Group - one of the world's largest mobile telecommunications company that has been undergoing strategic transformation from a traditional telecommunications operator - to a mobile (and later digital) service provider since the $2000 \mathrm{~s}$. Faced with increasingly high uncertainty and disruption of the business mode (Christensen \& Johnson, 2009; Osterwalder \& Pigneur, 2010), Telenor Group aim at continuous innovation and defined service design as a core capability of the firm. We gathered data over a period of 8 years, both retrospectively and in real time, within multiple markets of operation. Our findings show that gradually, through the use and co-alignment of dedicated resources, service design tools, training programs and boundary-spanning activities, service design has emerged into customer-centric business practices throughout the organization, new ways of working and, increasingly, into a commonly shared language of service innovation. This study contributes by bridging the emerging theory on service design with established strategy theory on organizational capabilities.

In the first part of the paper, we provide a critical overview of service design and organizational capability literatures where we specify research limitations. The second part of this paper describes our research setting, the method, data collection and analysis. In the third part, some of our emerging research findings are provided. Finally, we discuss how service design and design thinking literature contributes to the management domain, and viceversa.

\section{THEORETICAL BACKGROUND}

The literature on service innovation considers service design as a capability enabling firms to adapt to their changing environments and stay competitive sustainably (Kimbell, 2014; Ostrom et al., 2010). Various individual and organizational factors have been identified that facilitate or inhibit the service design thinking in an organization (Krinsky \& Jenkins, 1997). Yet, surprisingly little is known about how an individual and an organization interact in the development of service design capability. The tension in individual- 
organization interaction may vary at different stages of innovation process (Lane, Koka \& Pathak, 2006). Overall, the process dimension is often implied in these studies, but not studied in depth (e.g., Hertog et al., 2010). The dynamic capabilities literature (e.g., Teece et al., 2016) has recently argued that a life-cycle view and a process approach to capability development may enrich organization research (Helfat \& Peteraf, 2015; Laamanen \& Wallin, 2009). In this paper, we seek to link the insights gained from service innovation studies to a capabilities view of the firm. More specifically, we aim to explain the underlying processes and 'higher-order' routines (Winter, 2003) through which service design evolves as a dynamic organizational capability.

\section{Capability dynamics}

Organizational capabilities have in extant research been suggested to be stable in order for the organization to utilize the capability to harvest rents over time (Winter, 2003). However, organizational capabilities are also expected to be amendable in order for the capability to support activities that are relevant for the organization to perform in an externally changing market (Teece, Pisano \& Shuen, 1997). This can potentially lead to a rigidity paradox constituent in the conceptualization of dynamic capabilities (Schreyögg \& Kliesch-Eberl, 2007). Some conceptualizations of this amenability explain how capabilities follow a life-cycle, much similar to product-life cycles, where capabilities develop, mature and decline at different stages (Helfat \& Peteraf, 2003). Others suggest that some firms are better at changing their capabilities than other organizations when facing shifting external market conditions (Eisenhardt \& Martin, 2000). These firms are suggested to have dynamic capabilities that act on, and change, underlying ordinary capabilities (Helfat \& Maritan, 2007; Teece, 2014; Winter, 2003).

The term dynamic capabilities was coined by Teece et al. (1997). It refers to a pervasive framework in strategic management that attempts to explain sustained competitive advantage. The motivation behind the dynamic capabilities perspective was to integrate previous approaches such as competitive forces (Porter, 1980), strategic conflict (Shapiro, 1989), and the resource base view of the firm (RBV) (Barney, 1991; Penrose, 1959; Wernerfelt, 1984). The concept of dynamic capabilities is defined as the "capacity to renew competences so as to achieve congruence with the changing business environment" (Teece et al., 1997, p. 516). The extant literature is adamant that dynamic capabilities are built and cannot be bought in a market (Collis, 1994; Makadok, 2001; Savory, 2006; Teece et al., 1997). In this respect, the dynamic capability literature clearly shows the connection to the theoretical origins of the RBV, and the underpinning assumption that 
resources and capabilities explain competitive heterogeneity (Helfat, 2000). According to the RBV the resources that lead to competitive advantage are "unlikely to be available from others under terms that do not strip them of the net present value of the rent stream they are capable of generating" (Rumelt, 1987, p. 143), and should abide to the Valuable, Rare, Inimitable and Nonsubstitutable (VRIN) criteria (Barney, 1991).

Dynamic capabilities have been claimed to be central to innovation (Tidd, 2012), and the issue of how firms develop and renew their strategies (Volberda, Baden-Fuller \& van den Bosch, 2001) has been linked to organizational learning (Crossan \& Berdrow, 2003) and the development of organizational capabilities (Helfat \& Peteraf, 2003). The dynamic capabilities literature has recently called for a life-cycle view and a process approach for improved knowledge on capability development (Helfat \& Peteraf, 2015). Extant theory on capability development has emphasized how incremental, concurrent learning and managerial decisions influence the development of capabilities (Bingham et al., 2015). Researchers also argue that the development of new capabilities is related not only to the portfolio of existing capabilities but to the actions of competent individuals that enact organizational capabilities (Laamanen \& Wallin, 2009).

\section{Service design as an organizational capability}

Despite being increasingly addressed amongst business practitioners, the concept of service design has received rather limited attention in the research community (Johansson-Sköldberg, Woodilla \& Cetinkaya, 2013; Liedtka, 2014). Service design is defined as "an emerging occupation in which practitioners aim to understand customers, organizations, and markets; develop new or improved services and customer experiences; translate them into feasible solutions; and then help organizations implement them" (Fayard, Stigliani \& Bechky, 2016, p. 6). Service design is rooted into the general area of design thinking, a human-centered approach of framing problems and solutions (Kimbell, 2011a) - aiming at a balance between desirability (people's need and want), viability (meets business objectives) and feasibility (technologically feasible) (Brown, 2009). Service design shares the same philosophy, but with an additional focus on the organizational side of the service provider delivering a new or improved service over time to customers (Fayard et al., 2016).

Service design is often described as "what designers do", referring primarily to methods and tools for problem solving (Johansson \& Woodilla, 2009; Kimbell, 2011b) that are particularly relevant in contexts of high uncertainty and ambiguity (Liedtka, 2014; Waddock \& Lozano, 2013). Several 
management scholars have turned their attention to design in strategy (Dunne \& Martin, 2006; Liedtka, 2014). Researchers draw on the foundational tenets of design thinking, such as iterative cycles of learning (Seidel \& Fixson, 2013) and value co-creation which, as they argue, enable firms to adapt to changing environments and stay competitive sustainably (Kimbell, 2014; Ostrom et al., 2010).

The scant research on service design practices has been limited to discussions on the importance of design thinking to management (Gruber et al., 2015; Ostrom et al., 2010; Seidel \& Fixson, 2013). We still know little about how service design (and design thinking) evolves into an organizational capability, though issues about the development and change of service innovation capabilities (among others) have received increasingly high scholarly attention (Helfat et al., 2007; Helfat \& Peteraf, 2015). Various individual and organizational factors have been identified in the literature that facilitate or inhibit design thinking in organizations (Kimbell, 2014). Yet, surprisingly little is known about how an individual and an organization interact in the development of a service design capability.

In contrast to product innovations, service innovations have "gamechanging" characteristics (Nordin, Kindström, Kowalkowski \& Rehme, 2011), implying that even small changes to a service offering may require considerable changes within an organization as well as in interaction patterns with the end-users (Breunig, Aas \& Hydle, 2016). Implementation of service design, therefore, requires orchestration of complex processes that may help to create a holistic service experience for customers, employees and business partners (Ostrom et al., 2010). Overall, the process dimension at multiple levels of analysis is often implied in these studies, but not studied in depth (e.g. Hertog, van der Aa \& de Jong, 2010)

In this paper, we seek to uncover how multiple actors enact service design capabilities throughout an organization. By exploring the implementation of a service design initiative within one large international organization, we contribute to the life-cycle view of dynamic capabilities, and respond to the call for improved knowledge of the service design-strategy link (Michel, Brown \& Gallan, 2008). 


\section{METHODOLOGY}

We use a revelatory, theory-building case (Yin, 1994) in this paper and justify our approach (Eisenhardt, 1989; Eisenhardt \& Graebner, 2007) by the lack of knowledge of the service design-strategy link. We analyzed service design processes in a theoretically sampled research context - the Telenor Group - one of the world's largest mobile operators with more than 200 million subscribers and 36,000 employees operating in 13 markets across the Nordics, Eastern Europe and Asia. Faced with high uncertainty and disruption in the telecommunications industry since the late 2000s, Telenor embarked on a journey of implementing service design (SD) as a corporate capability. A number of strategic initiatives to incorporate SD practices in the operations and innovation activities were taken at the Telenor Group (HQ) and Business Unit level that led the company to discover new market opportunities, and redefine processes and managerial decisions. As such, our case company was an excellent exemplar of a large, multi-domestic corporation exploring service design as an organizational capability for innovation under high market uncertainty.

We used a longitudinal, exploratory case study approach because it allowed us to capture how service design practices evolved and led to multiple organizational outcomes, several of which were only observable over time. Examples of such outcomes are new leadership attitudes, incentive systems and ways of working. These organizational changes contributed to the creation of new interaction patterns with external stakeholders, thereby matching internal resource development with the demands of a rapidly changing business environment.

Our longitudinal data consists of historical and real-time data, which we gathered at different points of time, over the period 2008-2016. The use of service design methods and tools in various projects at the Group and Business Unit level (such as Customer Journey Mapping) served as multiple episodes. We conducted over 100 interviews with Telenor managers in corporate headquarters and in Business Units, participant and non-participant observations, took notes from multiple site visits and management training sessions, and collected other archival data (see Table 1 below). This approach allowed for triangulation of multiple data sources (Jick, 1979). We developed case narratives, used systematic analysis of informant stories and induced theoretical insights to identify and make sense of the emerging constructs (Gioia, Corley \& Hamilton, 2013). Two of this paper's authors worked in the company's research department and followed organizational processes from the inside, taking field notes, conducting interviews and informal conversations with organizational members, as 
well as participating and heading management training sessions for design thinking and innovation. Another co-author was external to the company who reviewed and commented on the findings. A combination of internal and external perspectives ensured the richness and trustworthiness of the data.

Table 1. Sources of data in different periods

\begin{tabular}{|c|c|c|c|}
\hline Period & Data type & Description & Amount \\
\hline \multirow[t]{3}{*}{ 2008-2013 } & \multirow{3}{*}{$\begin{array}{l}\text { Archival } \\
\text { documents }\end{array}$} & Customer Journey Mapping (CJM) documents & 40 \\
\hline & & Company presentations on CJM & 20 \\
\hline & & $\begin{array}{l}\text { Strategy documents (global and marketing } \\
\text { strategy focus) }\end{array}$ & $>10$ \\
\hline \multirow[t]{8}{*}{ 2014-2015 } & $\begin{array}{l}\text { Participant } \\
\text { observations }\end{array}$ & $\begin{array}{l}\text { Service Design Academies (SDA) across } \\
\text { Telenor } \\
\text { Innovation workshops }\end{array}$ & $\begin{array}{l}10 \text { (40 } \\
\text { participants } \\
\text { in each) } \\
3 \text { ( } 30 \\
\text { participants } \\
\text { in each) }\end{array}$ \\
\hline & $\begin{array}{l}\text { Non-participant } \\
\text { observations }\end{array}$ & mAGRI field visit (workshops, presentations) & 3 \\
\hline & \multirow[t]{3}{*}{ Interviews } & $\begin{array}{l}\text { Early frontrunners, including directors, } \\
\text { project/program managers, telco-related } \\
\text { experts, strategic advisors and in-house } \\
\text { designers) }\end{array}$ & 30 \\
\hline & & $\begin{array}{l}\text { Innovation interviews in Telenor BUs (senior } \\
\text { and middle-level managers across functions) }\end{array}$ & 75 \\
\hline & & $\begin{array}{l}\text { mAGRI project interviews (UX, service } \\
\text { designers, product managers) }\end{array}$ & 4 \\
\hline & \multirow{3}{*}{$\begin{array}{l}\text { Archival } \\
\text { documents }\end{array}$} & Strategy documents (innovation focus) & $>10$ \\
\hline & & Company's intranet news & Sporadic \\
\hline & & $\begin{array}{l}\text { Facebook@Work (interest groups on SD and } \\
\text { innovation) }\end{array}$ & Sporadic \\
\hline \multirow[t]{6}{*}{2016} & \multirow[t]{2}{*}{$\begin{array}{l}\text { Participant } \\
\text { observations }\end{array}$} & $\begin{array}{l}\text { Telenor leadership trainings (innovation, } \\
\text { strategy execution) }\end{array}$ & 2 \\
\hline & & $\begin{array}{l}\text { Telenor expert- and leadership trainings } \\
\text { (Design thinking, innovation) }\end{array}$ & 3 \\
\hline & Interviews & mAGRI project interviews (product managers) & 2 \\
\hline & \multirow{3}{*}{$\begin{array}{l}\text { Archival } \\
\text { documents }\end{array}$} & Strategy documents (BU focus) & $>10$ \\
\hline & & Company's intranet news & Sporadic \\
\hline & & $\begin{array}{l}\text { Facebook@Work (interest groups on SD, } \\
\text { design thinking and innovation) }\end{array}$ & Sporadic \\
\hline
\end{tabular}




\section{Service design in Telenor 2008-2016}

Empirically our study uses digital transformation in the telecom sector as a disruptive context to capture organizational capability development process. More specifically, we observe evolution in the service design capability in the case of one of the world's 15 largest mobile operators, Telenor. With its origin as a fixed telephony Norwegian state-owned monopoly, since the late 1990s Telenor has become one of the leading multinational mobile telephony operators. Through green-field investments and acquisitions, Telenor has evolved as a multi-domestic large corporation characterized by local autonomy of the affiliates. Each affiliate in the local market is defined as a Business Unit (hereinafter BU). In 2016, Telenor had over 200 million customers across its operations in $13 \mathrm{BUs}$ in the Nordic region, Central and Eastern Europe and Asia, with annual revenues of NOK 131 billion (USD 15,2 billion) and a workforce of 36,000.

Facing severe threats to traditional revenue sources, Telenor has moved swiftly into a strategy of exploring new business models aimed at transforming the company into a "Digital Service Provider". In order to reach growth ambitions, the company proactively considers the possibilities of building new, global digital products and services and replicating their use across the 200 million-customer base in 13 BUs. During the last decade a number of centralized functions, such as products and marketing, R\&D and technology were established to foster better integration of the Business Units and facilitate knowledge sharing across units and geography without losing the decentralized nature of the company. In that journey, building service design and design thinking as organizational capabilities for innovation is seen as important, and defined as a core capability in Telenor. Telenor has transitioned from exploiting customer frameworks of a limited scope across the BUs to strategically building innovation practices and new, agile ways of working with implications to culture across the overall Group.

In the following section we present the implementation of the customer journey mapping framework as one of the early episodes in the development of service design capability in Telenor. Then we move on to describing how design thinking practices were introduced and have become shared and replicable patterns of innovation and intrapreneurship throughout the organization. We emphasize the key challenges and dilemmas of Telenor in its journey of institutionalizing new capability where new and old business logics have to co-exist. 
Early episodes of service design - customer journeys

As a response to Telenor's strategic intent to offer a superior customer experience, the Customer Journey mapping Framework (CJF) was initiated in 2009. The framework was piloted in several Business Units and further developed in-house over the next four years (2009-2013). These pilots identified gaps between actual and planned customer journeys, and the implications to business in terms of, e.g., churn possibilities, overthrown customer service, and, ultimately, bad customer experience. Those insights caught management attention and contributed to some key managerial decisions that, in turn, brought institutional changes throughout the Telenor Group.

With the increased sense-making among middle-level managers, the CJF soon became a managerial metric for measuring customer experience and for implementing a new product into a service journey. This type of metric, however, implied tensions of using CJM instrumentally and as a strategic symbol only, i.e. by not engaging the customer and the customer experience in the mappings. One of our informants explained; "We are doing this [customer] mapping from the Telenor perspective actually because it is important for us to see what kind of resources we need for the service." Such usage of CJF was considered valuable for assessing the set-up of the value chain. However, it was utilized as a service blueprint bypassing the original intention to measure the customer's own experience of the existing value chain. Moreover, the customer journey mapping contributed to an increased understanding and practices of resource integration among different business actors across the existing value chains. Through the use of $\mathrm{CJF}$, a cross-functional collaboration was induced and a mutual understanding of superior market offerings from a customer perspective was created. One of our informants emphasized the CJF implications to the ways of working and thinking in Telenor: "[The customer journey maps] have helped us to think from a customer perspective, by bringing together process owners and customer-facing personnel. (...) For an organization that is used to thinking [of] profit perspective as the simple truth, it has changed our way of thinking." Gradually, the rhetoric of customer journey became a common and institutional language throughout Telenor.

Alongside creating new corporate language, the use of CJF increased consciousness regarding the root causes of bad customer experience. Over time, the Net Promoter Score (NPS) reporting standards have been used as a non-financial KPI (Key Performance Indicator) at different management levels across the entire organization. Due to a widespread uptake of NPS across Telenor, it has become a particularly useful means to gather insight into most prominent aspects of the service process that shape customer experiences. Yet, tensions between different corporate functions emerged, and a lack 
of end-to-end responsibility was highlighted. In parallel, and partly due to experiences gained from the CJF projects, an initiative to leverage strategic value of service design thinking was brought by Telenor HQ in late 2015/early 2016. The CJF was exploited as a corporate strategic tool across the overall Group, and service design was defined as a core organizational capability.

Later episodes of service design - Design thinking as innovation practice In 2016 executive management, expert- and leadership training programs on design thinking and innovation processes were launched as part of the new Digital Service Provider strategy in Telenor. Our observations indicate that certain principles of design thinking contributed to new leadership attitudes and managerial decisions. Gradually these evolved into commonly shared practices of innovation and intrapreneurship across Telenor. Design thinking has become more of a new philosophy - a new way of doing things - in the organization. As one of our informants underlined, "[The President] talks a lot about this, and this affects the organization gradually to develop."

By implementing the design thinking philosophy managers were able to seize new business opportunities, which they developed from synthesizing insights from in-depth user research and prototyping with customers. This represented a radical change in how and for what purposes user research was used in the organization. Beyond mere quantitative representation of market research and value chain mapping, user research practices have increasingly become the catalysts of innovation mindset in the organization, which was characterized historically by strong technology focus. One of the project managers explicitly emphasized this: "People generally think innovation is something like an idea. But before innovation comes research, and believe me: user research is the hardest and most important part of the process (...). You are not out there for finding solutions; you are out there for understanding - trying to understand what their thoughts, needs and problems are". To be able to discover unmet needs and potential new solutions, the value of empathizing with customers and rapidly getting feedback in learning loops of prototyping, has gradually seized changes in managerial decisions for innovation processes. One of our informants emphasized that "the decisions must follow what the customer values the most", and not making decisions based on assumptions or ready-made technological solutions: "We decided upon some few assumptions that our solution was based on, and tested and validated them through very simple rapid prototyping. Traditionally, we used a lot of time going back and forth in endless discussions".

A mobile agriculture service launch in Telenor Pakistan is a good example how principles of design thinking were utilized in the organization. In the 
mAGRI project, the challenge was to develop digital services in an untapped market with $50 \%$ of the country's working population in rural areas. Telenor Pakistan is among the country's leading mobile operators, and the project aimed at improving the livelihoods of farming households by empowering them with better access to information and financial inclusion. This ambition raised several challenges since tapping into this market involved limited literacy and technical experience as well as very limited customer purchasing power. The project team needed to involve local farmers to understand how services could be designed in a way that would be intuitively understood by potential users, yet maintaining a low cost structure. As put by one of the project leaders, "When you give a farmer a mobile and ask her to ring up a number, she listens to the service. Because we talked to her, we realized that the buttons were too hard for her to press. Insights like these are valuable for the process of creating new services." Faced with a complex value chain in the industry and an unknown customer base, mAGRI relied on service design methodologies to gain customer insight and, more importantly, alter leadership attitudes and organizational routines for service innovation, thereby matching the demands of rapidly changing environments.

This new way of thinking and doing things implicated a managerial sensing of the changes needed to the governance model for project execution. The dominant project governance model in Telenor was characterized by a business case in the initial phases, contained sequential steps with clear goals, pre-defined resources and large investments, and in which progress and success were measured against pre-defined deliverables and outcomes. To navigate in a highly uncertain environment and meet the demands of rapidly changing markets, the dominant project governance model was increasingly perceived as obsolete, particularly for innovation projects outside the core telco business. As described by one of the managers, "Telenor has a decision process and case approach that is tailored for large upfront investments with revenues spread over a long period of time. That process needs to be revised to cater for new business models". This area of tensions was identified by managers and generated new prototypes of governance models for innovation projects. As the Telenor Group CEO emphasized, "we must dare to establish projects without a clear business plan".

Over time, service design and design thinking have stimulated new, more creative ways of working and contributed to the creation of a shared language of innovation throughout Telenor. The initially scattered service design practices have gradually become shared and replicable patterns of service innovation throughout the organization. Yet, at the time of writing the paper, this journey was not complete and had been marked by a number of organizational challenges and dilemmas. Telenor and the telco industry, more 
generally, has been historically characterized by low risk appetite and risk aversity, relying on external vendors and consultancy services, which made it difficult to implement experimental and agile ways of working in-house. One of our interviewees argued that "people are (still) stuck in their old ways, afraid to make mistakes, always going for the known and safe option. (...) Words and speeches are all well and good, but actions and words have to be aligned for this change to happen." Furthermore, a traditional decision process was not suited to new ways of working (including design thinking and innovation). Experimenting within a hierarchical organizational structure was also difficult, and the company was lacking autonomous teams empowered to take rapid decisions. As put by one of the senior managers, "a degree of autonomy in decision making that is not tied to the usual corporate decision process is needed to translate an agile way of working into an actual outcome".

\section{CONCLUDING DISCUSSION}

The goal of this paper is to enlighten the mechanisms through which service design develops into an organizational capability, and by doing so, to bridge the emerging theory of service design and design thinking with established strategy theory on organizational capabilities. Through a longitudinal, exploratory case study of one of the world's largest telecommunications companies, we focus on how scattered service design practices become shared and replicable patterns of service innovation throughout the organization. Examples of such outcomes are new leadership attitudes, incentive systems and ways of working.

Our findings show how the initial pilot project was underpinned by a service design thinking related to customer centricity. Telenor utilize Customer Journey mapping frameworks (CJF) to compare Customer journeys. These CFJ are used to plan, identify gaps and in order to improve when necessary. As the CJF proved valuable to the way organizational members understood, interacted and made decisions concerning their customers. This way of work became increasingly diffused throughout the organization and institutionalized through new performance measures and training. Implementation of the customer journey framework was only one episode in the development of service design capability in Telenor, but it revealed critical dimensions of service design (such as customer co-creation, actor engagement across various components of a service) beyond the methodology itself. For example, a standardized use of an NPS metric, and subsequent KPIs, demonstrated an increasing ability (and shared language) to handle customer centricity. As such, service design thinking gradually disseminated throughout the entire organization. In this context, it is thus 
evident that managerial intentionality affects the multiple paths to capability development, as the service design initiative was a managerial decision. It is however, also important to point out that management did not have a direct role in all the customer-centric projects and subsequent learning situations, thus management intentionality can be understood as an initiating condition but further research is required to unmask the role of management throughout the process of building organizational capabilities. Further research should be emphasized on explicating how design thinking competence becomes diffused and institutionalized above organizational level, e.g., routines at the individual- and group-levels (Crossan et al., 1999). Moreover, as the project is still ongoing, we currently seek to identify to what degree locally built best practices and capabilities are transferable to other business units within the Telenor group, or to what extent they are susceptible to knowledge stickiness (Szulanski, 1996). There are also potential implications to practice from this study as it demonstrates how service design methodology can be implemented and have strategy implications for organizations.

Current research on organizational capabilities calls for an increased understanding of the emergence of organizational capabilities and their lifecycles (Volberda et al., 2010; Helfat \& Peteraf, 2015). Our study contributes to this stream of research by exploring the emergence of service design capability and theorizing the design-strategy link.

\section{References}

Barney, J. B. (1991). Firm resources and sustained competitive advantage. Journal of Management, 17(1), 99-120.

Bingham, C. B., Heimeriks, K. H., Schijven, M., \& Gates, S. (2015). Concurrent learning: How firms develop multiple dynamic capabilities in parallel. Strategic Management Journal, 36(12), 1805-1825.

Breunig, K. J., Aas, T. H., \& Hydle, K. M. (2016). Open innovation or innovation in the open? An exploration of the strategy - innovation link in five scaleintensive services. In A.-L. Mention \& M. Torkkeli (Eds.), Open Innovation: A Multifaceted Perspective (pp. 67-85). UK: World Scientific Publishing.

Brown, T. (2009). Change by Design: How Design Thinking Transforms Organizations and Inspires Innovation. London: HarperCollins.

Christensen, C. M., \& Johnson, M. W. (2009). What are business models, and how are they built? Harvard Business School Module Note, 610-019.

Collis, D. J. (1994). Research note: How valuable are organizational capabilities? Strategic Management Journal, 15 (Winter special issue), 143-152.

Crossan, M., \& Berdrow, I. (2003). Organizational learning and strategic renewal. Strategic Management Journal, 24(11), 1087-1105. 
Crossan, M. M., Lane, H. W., \& White, R. E. (1999). An organizational learning framework: From intuition to institution. Academy of Management Review, 24(3), 522-537.

Dunne, D., \& Martin, R. (2006). Design thinking and how it will change management education: An interview and discussion. Academy of Management Learning \& Education, 5(4), 512-523.

Eisenhardt, K. (1989). Building theories from case study research. Academy of Management Review, 14(4), 532-550.

Eisenhardt, K. M., \& Graebner, M. E. (2007). Theory building from cases: Opportunities and challenges. Academy of Management Journal, 50(1), 25-32.

Eisenhardt, K. M., \& Martin, J. A. (2000). Dynamic capabilities: Why are they?. Strategic Management Journal, 21(10/11), 1105-1121.

Fayard, A. L., Stigliani, I., \& Bechky, B. A. (2016). How nascent occupations construct a mandate: The case of service designers' ethos. Administrative Science Quarterly, 1-34.

Gioia, D. A., Corley, K. G., \& Hamilton, A. L. (2013). Seeking qualitative rigor in inductive research: Notes on the Gioia methodology. Organizational Research Methods, 16(1), 15-31.

Gruber, M., de Leon, N., George, G., \& Thompson, P. (2015). Managing by design. Academy of Management Journal, 58(1), 1-7.

Helfat, C. E., Finkelstein, S., Mitchell, W., Peteraf, M. A., Singh, H., Teece, D., \& Winter, S. G. (Eds.). (2007). Dynamic Capabilities: Understanding Strategic Change in Organizations. Malden, MA: Blackwell Publishing.

Helfat, C. E., \& Maritan, C. A. (2007). Dynamic capabilities and organizational processes. In C. E. Helfat, S. Finkelstein, W. Mitchell, M. A. F. Peteraf, H. Singh, D. J. Teece \& S. Winter (Eds.), Dynamic Capabilities. Understanding Dynamic Change in Organizations (pp. 30-45). Oxford: Blackwell.

Helfat, C. E., \& Peteraf, M. A. (2003). The dynamic resource-based view: Capability lifecycles. Strategic Management Journal, 24(10), 997-1010.

Helfat, C. E., \& Peteraf, M. A. (2015). Managerial cognitive capabilities and the microfoundations of dynamic capabilities. Strategic Management Journal, 36(6), 831-850.

Hertog, P. d., van der Aa, W., \& de Jong, M. W. (2010). Capabilities for managing service innovation: Towards a conceptual framework. Journal of Service Management, 21(4), 490-514.

Jick, T. D. (1979). Mixing qualitative and quantitative methods: Triangulation in action. Administrative Science Quarterly, 24(4), 602-611.

Johansson-Sköldberg, U., Woodilla, J., \& Cetinkaya, M. (2013). Design thinking: Past, present and possible futures. Creativity and Innovation Management, 22(2), 121-146.

Johansson, U., \& Woodilla, J. (2009). Towards an epistemological merger of design thinking, strategy and innovation. Paper presented at the 8th European Academy of Design Conference. 
Kimbell, L. (2011a). Designing for service as one way of designing services. International Journal of Design, 5(2), 41-52.

Kimbell, L. (2011b). Rethinking design thinking: Part I. Design and Culture, $3(3), 285-306$.

Kimbell, L. (2014). The Service Innovation Handbook. Amsterdam: BIS Publisher.

Kolko, J. (2015). Design thinking comes of age. Harvard Business Review, 93(9), 66-69.

Krinsky, R. J., \& Jenkins, A. C. (1997). When worlds collide: The uneasy fusion of strategy and innovation. Strategy \& Leadership, 25(4), 36-41.

Laamanen, T., \& Wallin, J. (2009). Cognitive dynamics of capability development paths. Journal of Management Studies, 46(6), 950-981.

Lane, P. J., Koka, B. R., \& Pathak, S. (2006). The reification of absorptive capacity: A critical review and rejuvenation of the construct. Academy of Management Review. 31(4), 833-863.

Liedtka, J. (2014). Perspective: Linking design thinking with innovation outcomes through cognitive bias reduction. Journal of product innovation management, 32(6), 925-938.

Lockwood, T. (2010). Design Thinking. Integrating Innovation, Customer Experience, and Brand Value. New York: Allworth Press.

Makadok, R. (2001). Toward a synthesis of the resource-based and dynamiccapability views of rent creation. Strategic Management Journal, 22(5), 387-402

Michel, S., Brown, S. W., \& Gallan, A. S. (2008). An expanded and strategic view of discontinuous innovations: Deploying a service-dominant logic. Journal of the Academy of Marketing Science, 36(1), 54-66.

Nordin, F., Kindström, D., Kowalkowski, C., \& Rehme, J. (2011). The risks of providing services: Differential risk effects of the service-development strategies of customisation, bundling, and range. Journal of Service Management, 22(3), 390-408.

Osterwalder, A., \& Pigneur, Y. (2010). Business Model Generation: A Handbook for Visionaries, Game Changers, and Challengers. New York: John Wiley \& Sons.

Ostrom, A. L., Bitner, M., Brown, S., Burkhard, K. A., Goul, M., Smith-Daniels, V., \& Rabinovich, E. (2010). Moving forward and making a difference: Research priorities for the science of service. Journal of Service Research, 13(1), 4-36.

Penrose, E. T. (1959). The Theory of the Growth of the Firm. New York: John Wiley \& Son.

Porter, M. E. (1980). Competitive Strategy. New York: Free Press.

Prahalad, C. K., \& Hamel, G. (1990). The core competence of the corportation. Harvard Business Review, 68(3), 79-91.

Reason, B., Løvlie, L., \& Flu, M. B. (2015). Service Design for Business. A Practical Guide to Optmizing the Customer Experience: New York: Wiley. 
Rumelt, R. P. (1987). Theory, strategy and entrepreneurship. In D. J. Teece (Ed.), The Competitive Challenge (pp. 137-158). New York: Harper \& Row. Savory, C. (2006). Translating knowledge to build technological competence. Management Decision, 44(8), 1052-1075.

Schreyögg, G., \& Kliesch-Eberl, M. (2007). How dynamic can organizational capabilities be? Towards a dual-process model of capability dynamization. Strategic Management Journal, 28, 913-933.

Seidel, V., \& Fixson, S. (2013). Adopting "design thinking" in novice multidisciplinary teams: The application and limits of design methods and reflexive practices. Journal of Product Innovation Management, 30(1), 19-33.

Shapiro, C. (1989). The theory of business strategy. RAND Journal of Economics, 20(1), 125-137.

Stickdorn, M., \& Schneider, J. (2012). This is Service Design Thinking. Amsterdam: BIS Publisher.

Szulanski, G. (1996). Exploring internal stickiness: Impediments to the transfer of best practice within the firm. Strategic Management Journal, 17 (Winter Special Issue), 27-43.

Teece, D., Peteraf, M., \& Leih, S. (2016). Dynamic capabilities and organizational agility. California Management Review, 58(4), 13-35.

Teece, D. J. (2014). The foundations of enterprise performance: Dynamic and ordinary capabilities in an (economic) theory of firms. The Academy of Management Perspectives, 28(4), 328-352.

Teece, D. J., Pisano, G., \& Shuen, A. (1997). Dynamic capabilities and strategic management. Strategic Management Journal, 18(7), 509-534.

Tidd, J. (2012). From Knowledge Management to Strategic Competence: Assessing Technological, Market and Organizational Inoovatation. London: Imperial College Press.

Volberda, H. W., Baden-Fuller, C., \& van den Bosch, F. A. J. (2001). Mastering strategic renewal: Mobilising renewal journeys in multi-unit firms. Long Range Planning, 34(2), 159-178.

Waddock, S., \& Lozano, J. M. (2013). Developing more holistic management education: Lessons learned from two programs. Academy of Management Learning \& Education, 12(2), 265-284.

Wernerfelt, B. (1984). Resource-based View of the firm. Strategic Management Journal, 5(2), 171-180.

Winter, S. G. (2003). Understanding dynamic capablities. Strategic Management Journal, 24(10), 991-995.

Yin, R. K. (1994). Case Study Research: Design and Methods. Thousand Oaks: Sage.

Yoo, Y., \& Kim, K. (2015). How Samsung became a design powerhouse. Harvard Business Review, 93(9), 72-12. 


\section{Abstract (in Polish)}

Ten empiryczny artykuł bada proces postępowania, poczqwszy od decyzji menedżerskiej, w którym projekt usług jest zdolnościq organizacyjnq, zgodnie z tym, jak rozwija się $w$ czasie $w$ ramach jednej organizacji. Projekt usług stał się znanq praktykq biznesowq, diagnozujqca $w$ jaki sposób firmy tworzq nowe produkty $i$ usługi w celu promowania zróżnicowania $w$ coraz bardziej niepewnym otoczeniu biznesowym. Niejawne w literaturze dotyczqcej projektowania usług sq założenia dotyczqce strategicznych implikacji przyjęcia określonych metod i narzędzi innowacyjnych. Jednak niewiele wiadomo na temat tego, jak projekt usług zmienia się w organizacyjnq zdolność, umożliwiajqca firmom przekształcanie istniejących firm i utrzymanie konkurencyjności. Poprzez podłużne, odkrywcze studium przypadku dotyczqce praktyk projektowania usług w jednym z największych na świecie firm telekomunikacyjnych, przedstawiamy mechanizmy, dzięki którym projekt serwisowy ewoluuje do możliwości organizacyjnych, zadaja pytanie badawcze: jakie sq mechanizmy, dzięki którym projekt serwisowy rozwija się w organizacyjnq zdolność? Nasze badania ujawniaja wpływ wstępnego wprowadzenia narzędzi do projektowania usług, identyfikacji podmiotów zajmujqcych się zakresem granic oraz współregulacji zasobów dedykowanych między funkcje wewnętrzne, a także poprzez współtworzenie z klientami. Z biegiem czasu działania te prowadza do przyjęcia praktyk w zakresie projektowania usług, a następnie te praktyki sq wprowadzane stopniowo w całej organizacji, zmieniaja decyzje kierownicze $i$ wpływajq na wiele ścieżek rozwoju nowych możliwości. Raportujqc ten proces, możemy opisać, w jaki sposób praktyki projektowania usług zostały rozpowszechnione i zinstytucjonalizowane w organizacji, którq obserwowaliśmy. Niniejsze opracowanie przyczynia się w ten sposób do informowania, w jaki sposób projekt usług może ewoluować w możliwości organizacyjne, a także poprzez powiqzanie powstajqcej literatury poświęconej projektowaniu usług z myśleniem o projektowemu z ustalonq teoriq strategii. Konieczne będq dalsze badania w celu potwierdzenia, czy te same mechanizmy sq możliwe do zaobserwowania w różnych kontekstach iw innych firmach, a także kilka przyszłych kierunków badań. Ponadto badanie ma również implikacje dla praktyki, ponieważ pokazuje, w jaki sposób metodyka projektowania usług może być wdrożona i ma strategiczne implikacje dla organizacji.

Słowa kluczowe: rozwój zdolności; myślenie projektowe; możliwości organizacyjne; praktyki projektowe usług; powiqzanie strategiczno-innowacyjne. 


\section{Biographical notes}

leva Martinkenaite is a Vice President at Telenor Research, heading the Telenor-NTNU Al-Lab and Internet of Things (IOT) initiatives. She holds a Ph.D. in Strategic Management from the BI Norwegian Business School, and a Master's degree from K.U.Leuven. Her research focuses on innovation and organizational learning processes in large corporations with emphasis on HQ-subsidiary relations and mergers and acquisitions. Contact: ieva. martinkenaite@telenor.com.

Karl Joachim Breunig is a Full Professor of Strategic Management at the Oslo Business School, Oslo and Akershus University College. He received his Ph.D. from the BI Norwegian Business School, and holds an MSc from the London School of Economics. Prof. Breunig's research concentrates on topics such as service innovation and digitalization in professional service firms, as well as strategic management, measurement and internationalization of knowledge work. Contact: karl.joachim.breunig@hioa.no.

Annita Fjuk is a Fellow at Telenor Research and Research Director/Professor at the Center for Service Innovation (NHH Norwegian School of Economics). She holds a Ph.D. in computer science with focus on participatory design from the University of Oslo. Her research focuses on design thinking in innovation, and particularly related to organizational transformation, governance and leadership. Contact: annita.fjuk@telenor.com. 
